This is the post print version of the article, which has been published in Representation. 2018, 53 (3-4), 219-231. https://doi.org/10.1080/00344893.2017.1393454

Tiina Rättilä, Jarmo Rinne

\title{
Local Resident Activism and Unofficial Political Representation: New Theoretical Contours
}

\section{Introduction}

In this article we analyse and discuss local resident activism as a rising phenomenon of political activism. In general terms, activism refers to action intended to produce social, political, economic, environmental, or ideological change (Gilster 2013: 33-34). Resident activism thus denotes a form of self-organising agency in localities, the intention of which is to effect change in people's immediate environment and neighbourhood. ${ }^{1}$

Like many other forms of new social movements and civic activism, resident activism operates outside formal political institutions and is motivated by the prospect of engaging in do-it-yourself (DIY) politics at the grassroots level. Yet, as distinct from other categories of social movements, like issue- and identity-based new social movements, local resident activism is characterised by a strong sense of commitment to a geographically, historically, and socially defined place. Indeed, resident activists are typically driven by ethical concerns related to their own environment, and engage in polymorphic activities to advocate for its well-being. Activities can vary from smallscale social gatherings for promoting community spirit, to large, enduring development projects to restructure the physical, economic, and cultural base of the neighbourhood, as well as Not-InMy-Backyard types of resistance to the public power's ventures that the residents deem harmful to the area. ${ }^{2}$

Recent scholarship on sociologically oriented social movement study has identified this form of local civic action - variously titled, for example, as neighbourhood-focused activism or DIY urbanism (Gilster [2013]; Fabian and Samson [2015]) - as an increasingly important form of activism. Studies show that while both traditional political participation and large-scale protest politics have declined, self-organised neighbourhood festivities and hybrid events that combine civic activities with protest events have become more frequent (see McAdam et al. [2005]; Sampson et al. [2005]; Gilster [2013]). In the political science research, however, this phenomenon has largely been ignored in the midst of otherwise lively discourse on the discontent with Western representative democracy. There may be several reasons for this lack of attention, but one arguably stems from the presumption that, when compared to the big political stakes at the national and international level, local democracy and civic action have only minor value in the overall game of politics. 
Further, there has been a long-enduring tendency by researchers, politicians, and the media to distrust the legitimacy of 'self-appointed' civic activism because it lacks general representativeness and accountability (Wills [2016a: 82-83]; [Wills 2016b]; [Montanaro 2012]). As a consequence, civic activism and representational politics have been treated as separate spheres of action and have even been juxtaposed to one another as modes of doing democracy. Hence, the issue of how civic activism and activists in reality relate to the idea and practice of political representation has not received proper attention. Here we take up the important question, who and what the civic activists themselves think they are representing with their activism, and how they justify their actions in relation to the ideas and institutions of existing representative democracy.

We approach our subject by applying the recently re-formulated ideas of political representation (Näsström [2011]; Saward [2010]; Severs [2010]). Conventionally, political representation has been understood in terms of a principal-agent relationship that is authorised and accounted for via the electoral process (see Pitkin 1972). The newer concept takes a different path and perceives representation as a broader political and cultural phenomenon. Herein it is accepted that unofficial non-institutional agents, such as celebrities, artists, and civic movements, may also claim and perform themselves - or be claimed by others - as representatives of issues and constituencies in such a way that carries political significance and can, moreover, influence the way people judge the actions and legitimacy of their institutionally authorised representatives. As we will argue, the difference between these two conceptions rests in that in the case of unofficial representation, both mandate and accountability depend on how people evaluate and judge the performance of the claimed representative on an ongoing basis. Unofficial representation consequently constitutes a dynamic and contingent process in which the representatives and the represented are engaged in a continuous interaction as though in a non-stop election campaign.

The activities of local civic movements can, more specifically, be characterised as prefigurative representation. Because such movements' primary reason for existence is to promote change to the prevailing politics, and because they have no institutional power to back up their visions and demands, they have to appeal directly to the people-as-audience for attention and support. In this way, the movements are predicatively entangled with the politics of the future, attempting to distinguish, portray, and manifest, that is pre/figure, their alternative to the existing order by doing and publicly showing what they claim to be representing.

The empirical data of the article consists of 13 theme interviews conducted with a variety of ongoing resident movements in Finland. Our phenomenologically oriented analysis focuses 
especially on two issues: (1) Resident activists' views on the functionality of local democracy in their own municipalities, and (2) their conceptions of the representativeness of their action. While our qualitative data is certainly limited and the findings are in no way conclusive, they do lend evidence to fresh hypotheses about how political representation today works, and what the prerequisites of democratic legitimacy are in conditions where political trust towards conventional politics and political actors is continuously decreasing.

\section{Background}

For a number of years now, both students of democracy and the representatives of public power in Western democracies have been concerned with the declining levels of popular interest, trust, and participation in politics (Dostie-Goulet [2009]; Tormey [2015]). At the same time and as a response to citizens' growing distrust in institutionalised politics, governments and scholars have explored the possibilities of democratic innovations, such as variations of deliberative forums and procedures, to remedy the problems. There are, however, more critical views according to which Western democracy can no longer be sustained in its current representative form, as it has perpetually failed to guarantee citizens, especially marginalised groups, an equal access to political voice and representation (Gaus 2008: 27-28). Moreover, a growing number of scholars are progressively worried about the impotence of representative democracies in terms of being able to address such boundary-transgressing problems as climate change, terrorism, the instabilities of a global economy, and the ongoing immigration crisis. It is difficult to see how such problems can be addressed resiliently without the input of global and local civil movements for their ongoing governance (see, e.g., Keane 2009).

In this unbalanced context, it has become necessary to think more seriously about the role and legitimacy of civic activism in democratic politics (Juris [2012]; Tormey [2015]). Prior research on democracy and civic movements has debated whether new political movements, such as the World Social Forum, the Arab Spring, the Spanish Indignados, and Occupy Wall Street, should be seen as remedying or even replacing traditional democratic institutions (della Porta [2013]; Juris [2012]). However, the discourse on the problems of democracy has been to date insufficient in that it has not included systematic empirical knowledge for how civic activism and activists in fact think about and relate to the ideas and institutions of political representation. The importance of this question grows apace with the declining trust in the established democratic system. Therefore, we have good reasons to look into how civic movements can be interpreted from the perspective of political representation, and whether they can even be taken as an entirely new generation and fashion of doing representative politics (Montanaro 2012: 1094-1095). 
Currently there is a gap, both theoretical and practical, between the representative institutions and civic activism which makes it hard to imagine and redesign workable alternatives to the present system. It is of no help when addressing this void that researchers on democracy, civic movements, and political representation tend to go their separate ways. The purpose of this article, therefore, is to respond to this deficiency and ruminate at least tentatively, by using empirical research, on the relevance of civic and resident movements for today's representative democracy.

\section{Theoretical Framework: Prefigurative Representation}

The idea and practice of political representation has intrigued political thinkers for centuries. The concept of representation itself has long and variable roots in the arts, philosophy, and religion, while the system of political representation developed as a practical solution for the problem of legitimising state power in the face of rising social classes and professional groups that have demanded political influence in the modernising society (e.g. Pitkin 1972). The distinctive capacity of the representative system to co-opt in its sphere ever new social groups that demand political representation has for a long while functioned as an efficient way of negotiating and balancing political conflict in Western liberal democracies.

According to critics, this logic is now in serious trouble. This challenge should not come as a surprise, considering that social and political theorists have for decades drawn attention to such developments as the disintegration of social structures, changes in production and labour, the development of new communication technologies, the increasing fluidity of state borders and power, the fragmentation of identities, and the individualisation of lifestyles (e.g., Heller and Feher 1989). As a result, traditional collectivities have gradually eroded, altering also the ways and spaces of political agency. According to Simon Tormey's (2015) recent argument, citizens no longer support the representative system as gullibly as they have historically, and they now refuse to be spoken for and represented by the old political elites.

Tormey claims such social changes to be so deep and irreversible that political representation is becoming virtually impossible. However, while Tormey's view is fresh and stimulating, we need not accept its conclusion at face value. Our counter argument is that despite fundamental transformations in the structure of the late modern society, the idea and practice of political representation itself has not lost its meaningfulness. Yet, we agree with many of the critics that it is necessary to see that the scope and relations of representation today extend from traditional electoral democracy and principal-agent relationships to the whole society more generally. In order 
to understand what is currently going on within the more widely defined politics of representation, we need to ask where, how, and by whom representation today is done and how the different concepts of representation are used in actual political discourse and struggle (cf. Pitkin [1972]; Mansbridge [2011]; Montanaro [2012]; Rehfeld [2011]; Urbinati and Warren [2008]).

We approach the politics of Finnish resident activism as prefigurative representation, stressing especially its aesthetic and performative connotations (Ankersmit [2002a: 115-117]; Saward [2010: 35-36]; see also Papacharissi [2015: 96]). Prefiguration refers to the projection of alternative (e.g., non-hierarchical, cooperative, dispersed, solidary, and playful) social and political relationships in the present time. The concept was defined in the 1970s by Carl Boggs (1977:100), in the context of his study on the new American New Left, 'as the embodiment, within the ongoing political practice of a movement, of those forms of social relations, decision-making, culture and human experience that are the ultimate goal' (see also Yates 2015). Prefiguration as an idea sits well with political, civic and resident movements because they are characteristically idealistic and visionary. In pursuing social and political change, they attempt to distinguish themselves clearly from the old order by producing noticeable and even spectacular alternatives to it, as for example the global Occupy movement did when it took over public parks and developed to the occupied spaces a direct democratic way of governance (Juris 2012).

The concept of prefigurative representation directs attention to the constructive and performative features of representation. Constructivity here means that there are no ready-made objects with clearly definable features that someone can simply take and re/present before others. Rather, objects need first to be constituted in order to render them representable (Ankersmit [2002a, 2002b]; Saward [2010: 4]). Moreover, since the representative constructs cannot simply portray already existing objects and their characteristics, they must, ipso facto, be aesthetic projections, and the venturing political actors must somehow be able to bring forth and manifest the represented objects via their own declared words, deeds, and images to make them comprehensible (Ankersmit 2002b).

Representation also requires that the actors be able to present convincing claims about their eligibility and ability to represent others' qualities, values, aims, and interests, as Michael Saward has pointed out (Saward 2010: 66). In this sense, political representation resembles the performing arts rather than merely a simple depiction of an existing idea or group. Representations are designed and 'done' and cannot exist without target audiences toward which they are suggested and performed. On the other hand, because representation entails an active communicative relationship between the claim maker and its target audience, it is always in the latter's power to 
decide whether or not it accepts the claim maker as its acknowledged representative.

\section{Research Material and Methods}

Finland is a parliamentary democracy with a unicameral parliament, separation of powers, and a strong multi-party system relying on the system of proportional representation (Arter 1999, 149149). Executive power is divided between the central government with its state level and regional agencies, and the local government exercised in 311 municipalities (as of 2017). Finnish municipalities enjoy a high level of local autonomy, the roots of which go back to the $19^{\text {th }}$ century when Finland was a part of the Russian Empire. Today, local authorities share a broad responsibility for the provision of basic public services to their residents, including children's day care, schooling, social and health care services, maintenance of the municipal infrastructure, town planning and zoning, maintenance of fire brigade units, and law enforcement. A municipality is governed by a proportionally elected municipal or city council serving a four-year term. Each municipality is required to have a municipal council, a local executive, and a committee for auditing municipal administration and finance.

Alike other Western democracies, in Finland traditional forms of political participation, like voting and party membership, have lost popularity (Bengtsson \& Christensen 2016, 234). The voter turnout has been low especially in municipal elections (below 60\% in the April 2017 elections). This has been considered problematic for democratic legitimacy given that the Finnish municipalities possess notable independence in their decision-making, including the all-important right of taxation. On the other hand, even as citizens are less and less tempted by traditional political participation, various alternative modes of political participation and action have proliferated at national as well as local level. Social movements and other forms of civic activism have become a significant channel for many citizens' political expression, and yet especially local movements and their role in democracy are still poorly known in political research. In this context, it is interesting to explore what local resident activists in Finland do think about the meaning of their own actions in relation to the idea and practices of political representation and local democracy.

The gathered material consists of 13 theme interviews with as many Finnish resident movements, conducted between February and June of 2015. Seven of the movements were selected based on prior knowledge of the movements and by contacting other researchers and activist networks. The other six were selected based on an analysis of media material. The purpose of the media analysis was to map out how widely spread resident activism as a phenomenon is in Finland and explore 
the scope of their activities.

The media material was gathered from five provincial newspapers and the Finnish Broadcasting Company's news on the Internet, using as search words combinations of 'resident' + 'municipal resident' (Finnish: 'kuntalainen') + 'activist' (Finnish: 'aktiivi') + 'activism' + 'movement', between 1 January and 31 December, 2014. The search produced 200+ articles, which in the first round of the analysis were read fully to identify the movements, their localities, and type of activities. In the second round, ten movements (50 articles) were picked for closer thematic analysis, and from this group, six movements were chosen to be interviewed in addition to the earlier seven others. The 13 movements were, all in all, selected to offer a comprehensive picture of the themes and forms of action of Finnish resident activism and find related examples from all parts of the country. ${ }^{3}$

To set up the interviews, the selected movements were contacted through phone, email or Facebook according to contact information found on the Internet. Replies were received from the predicated chairpersons of the movements, two of which declined to take part in the research and were replaced by other similarly profiled movements that were active in the area. Each movement was free to decide on the person(s) participating in the interview. In practice, all of the interviewees acted as the chairperson(s) of their movement. By their own choice, many of the movements wanted to be interviewed in a group of two or three activists. There were altogether 23 interviewees, of whom 11 were women and 12 were men. All interviews were videoed and audio recorded, and then transcribed. ${ }^{4}$

The interview method was based on a phenomenological approach, which gives space for the interviewees to offer their own subjective experiences and reflections (Drudy et al. 2005). Personal experiences are important because, according to phenomenological thinking, they describe the subjects' conceptions of the problems at hand as well as their judgment of the kind of action necessary to address them. By looking closely into the studied subjects' experiences, researchers are able to tap into and consider the reasons that motivate their actions in each instance (Zahavi 2009). In practice, this method lets interviewees answer and elaborate on the questions freely without interruptions, which is why phenomenologically oriented interviews are often lengthy. In this particular case, the interviews lasted from 40 minutes to 2.5 hours, and altogether more than 18 hours of material was filmed and audio recorded.

The material was analysed using theory-guided content analysis (Krippendorff 2012), which focused on the interviewees' conceptions of the representativeness of their actions. ${ }^{5}$ The analysis 
of the material were conducted inductively, paying close attention to those expressions that started recurring in a long interview and could be thought to crystallise the meanings important to the interviewee. Single thematic answers were interpreted in light of these reiterated expressions as part of more structured narratives. Utterances that were considered central to those narratives were compiled together from each interview, and three general classes of meanings were then formulated on that basis. ${ }^{6}$ Findings were, in the end, reflected on against the ideas of prefigurative representation as well as the relevant research literature.

\section{Analysis: Resident Activism as Prefigurative Representation}

In order to put resident activists' conceptions of representation in the proper context, we looked at how the interviewed activists see the current state of democracy in their municipalities. The interviews demonstrated that the resident activists' relationship to their municipal government and decision-making has become weaker and more irrelevant than earlier. Nearly all interviewees indicated that influencing local planning and decision-making is very difficult. They also felt that local politicians were uninterested or unable to solve the problems that local people considered important. Residents' concerns were bypassed for example by claiming that they were not in the general interest of the whole municipality. Activists were especially critical of party politics, and many wondered why political parties are needed in local democracy in the first place. Instead of relying on parties, politicians, and officials, these activists felt that they had to take responsibility for the affairs of their locality into their own hands:

INT 4: (- -) clearly it is obvious that our municipal decision-making system is in no way sufficient. It is not, to tell it straight out, able to produce qualified decisions enough without involving residents in it.

INT 12: I feel that our action is like one sign of that democracy doesn't work. Because, well, people have had to start doing things themselves since they feel that they have not been given the sort of influence in their own neighbourhood (- -).

On the other hand, activists' experiences of municipal democracy seemed to vary between urban and rural areas. Especially in the largest cities, the residents' movements took actively part in planning policies, sometimes in opposition to proposed projects and sometimes in cooperation with the planners. In many rural areas instead, the hold of the traditional political culture which privileges party-centred representation prevented residents from getting actively involved in the local politics. The experience of the majority of the interviewed activists was, however, that decision-makers are either not able or unwilling to see residents as experts on the issues concerning 
their own localities. As one of the interviewees explained:

INT 1: (- -) it feels bad that residents are not being heard, that they [decision-makers] just come and show you their decisions (- -) So, public servants can, sort of, just bypass local knowledge and experience by thinking that it is not universal enough. (- -) in that sense it is a rather violent perspective because it does not allow the local people the opportunity to say anything.

Respectively, the relationship of the activists to other residents in their area appears to have strengthened. This can be taken as a sign of residents attempting to address their felt lack of social belongingness, trust, and shared identity brought about the transition of traditional municipal politics towards the late-modern style of managerialism and business orientedness. In the interviews, the activists expressed their aspiration to build a more solidaric and collective way of life in their neighbourhoods. Some activists were also motivated by a desire to disrupt the local politics and make their critique of the existing system more publicly visible. Yet, the ultimate purpose of the residents' activism was not to bicker with officials and decision-makers even though their relationship was sometimes tense. What mattered most to activists was achieving concrete results. Collaboration with the local government, therefore, was not seen as an impossible option whenever it was judged useful.

In terms of their conceptions of the representativeness of their own actions, our interviewees did not initially refer to their own activity explicitly as representation. In fact, the question of whether they thought they were representing something or someone in their movement was to many baffling at first. The typical answer was in the form of 'well, nobody has elected me for this or anything.' However, after thinking about the issue for a moment, most of the interviewees did assert that they represented other likeminded residents in the area. Moreover, and interestingly, once this idea surfaced, it kept coming up during the interview, as if the whole idea had just then for the first time become clear to the interviewees. Many shared ideas similar to this activist:

INT 2: (- -) at times I see myself representing more myself, and then on other occasions perhaps more XX [the neighbourhood]. (- -) And those who share our view then have found a channel to agree with us and to promote issues from these perspectives which we have started from (- -)

The preliminary difficulty with answering the question about representation clearly had to do with the activists' sharing a paradigmatic view of political representation in terms of electoral democracy. Most resident and civic movements, to be sure, lack election-bound authorisation, as 
the interviewees readily pointed out. Moreover, they also insisted on distinguishing their actions from parties and local power cliques. For the interviewed activists, the 'right' kind of politics seemed to equal living up to a set of predefined ethical principles and not an instrument for seeking power and defending party interests. This finding was no novelty, however, since the tendency to avoid 'politics' seems to characterise much of the contemporary civic activism in Western democracies. As one of our interviewees put it, 'Here [in the movement] politics has not played any role. Our intention is only to improve our near environment.' (INT 2)

The question of the relationship between resident activists and political representation produces further nuances when we look at how the activists described their actions in their own words. It was notable how firmly they stood behind their own visions and projects regarding the future of their locality and saw them both necessary and justified. Our interviewees were unmistakably proud of their area and its history and were highly motivated to enhance its well-being, ecological as well as social and political, through their own projects and efforts. As we see it, such action can be characterised as prefigurative; its aim was to produce social, political, and ecological change by providing concrete, visible examples of how things in the area could be different.

The interviews also demonstrated that the activists were well aware of their role as the figurehead of their movement, thus implying that even though they may not have been officially elected to their positions, they did receive authorisation from other residents, i.e., those 'who come to the meetings' or who come and say 'it was about the time someone did something'. In the words of one interviewee:

INT 9: (- -) we in a way represent those people who think alike, and they have not had the capacity to bring it up in any other way than by joining this association. And they have then given the few of us the mandate, so that we can be the board of the association and act there the way we see is best (- -).

That the interviewed activists had at least unconsciously assumed a role as a political representative appeared also in how they stressed that working as a figurehead of the movement in the public eye was a time-consuming and strenuous responsibility. Yet, the activists accepted this role as it was important for the functionality of the movement. Contrary to a common assumption in contemporary social movement studies, not all new movements (if any) are in fact leaderless, even if they prefer to portray themselves as such. In practice, and for the sake of ensuring the functionality of the movement, at least some measure of effective leadership is needed and even expected by the supporters of the movement. However, the new movements avoid 
traditional, hierarchical leadership structure and prefer instead a soft and informal type of leadership that stresses simplicity, flexibility and working together in the execution of the movements' activities (see Gerbaudo 2012). Indeed, our interviewees noted that they favoured working together with others whenever possible. There was more gratification to be found in their acting together with other like-minded residents than in trying to push things forward alone.

When we think about the resident activists' relationship to political representation, it is important to note that their stand on the existing system is critical and not adversarial. Like citizens in Finland generally, resident activists do not question the value of local democracy even in its representative guise. In fact, the interviewed activists had many ideas about how to reform municipal democracy to make it more resident-oriented. First, some suggested that decision-making in the municipality needed to be decentralised and re-localised to give residents real decision-making power and better resources. Their argument was that since municipalities in Finland take care of such a wide variety of statutory and non-statutory functions, some of these could be handled in the neighbourhoods, while others (like traffic and education) were better decided on a higher, regional level.

Another very practical idea that appeared in the interviews concerned resources. In this respect, the activists' aspirations were often modest and yet crucially important to themselves. Residents were hoping for their municipality to provide minor tangible resources, like building materials, to carry out their projects, as well as provide a common space for meetings and social gatherings. Third, many activists mentioned the positive role of specially assigned project workers or participation coordinators who mediate between the administration and the residents. In their experience, skilful mediators often manage to procure the residents small resources from the administration, and while traversing between residents and the municipal government, also channel information to both sides about what is going on in the neighbourhood on the one hand and in the decision-making process on the other.

We also observed that skilful mediators might even influence the activists' view of the legitimacy of their local government. Those resident movements that had benefited from the help of efficient coordinators tended to evaluate their own influence on planning and decision-making more positively than did those movements that lacked this kind of resource. We saw this finding as curious, considering that a bulk of political and democratic theoretical discourse has for years stressed the need to expand citizens' official participation opportunities. Our finding suggests that personal participation in official processes may not always be necessary for citizens to judge democracy as working properly. At least based on our limited qualitative data, the crucial condition of legitimacy seems to be that citizens are able to engage in various DIY activities while at the same time maintaining a communicative relationship with other democratic institutions through 
some kind of mediating agent.

Fourth and most importantly, the activists stressed their own expertise and localised experiential knowledge which they hoped local politicians would use more for planning and decision-making. Officials' power in terms of planning should be diminished, or at least their role should be rethought to serve the residents' needs better and prevent the local government from going forward with plans for the locality without consulting the residents first. Activists widely questioned the assumption that officials and elected decision-makers know better than residents do what is best for their municipality:

INT 1: I can't even imagine that kind of option where you just let somebody else decide what happens in your life (- -). I can't think of any reason or justification for why some public servant should decide on people's lives ( - -). Why should that power be taken away from the local community (- -)?

\section{Conclusions and Discussion}

From the point of view of actual political representation, civic and resident activisms are an intriguing topic of research because recent changes in political agency materialise so visibly in their growth. Politics has become an everyday matter, and citizens now perceive themselves as experts about their own life world beside and even beyond the idea of professional politics. Local resident activism is one example of such changes. Our interviews demonstrate that even though in terms of geographical space municipal decision-making takes place basically close to residents, in terms of mental political space, the two are yet wide apart. Moreover, resident activists do not trust official participation opportunities, as their first-hand experience has proven them to be formal and staged rather than real and effective.

When we look at resident activism in terms of democratic theory, it is interesting to ask whether and to what extent resident activism can be democratically justified as a form of representation. Normatively speaking, the problematic question concerns the authorisation of power and its process. While traditional representation is based on the power of speech and negotiation delegated to the representative through elections or some other officially sanctioned selection method, resident activists' representation lacks such a formal authorisation. Instead, their representation is justified informally through prefigurative action performed for, and accepted by, other residents. Therefore, while traditional representatives gain their mandate before actual representation begins and their accountability is achieved in the next elections, civic and resident activists must basically find merit for their mandate dynamically every day anew. As unofficial representatives, they make and perform representations outside the electoral institutions and public authority structures. 
According to the institutionalised account of representation, the absence of electoral authorisation and accountability renders the representations of non-elected resident activists suspect and even illegitimate. However, resident activism need not be placed in such a straight-forward juxtaposition to institutionally sanctioned representation. Local resident activists generally do not question the authority of the state or the local government, even if they exercise the now popular critique towards elected politicians and parties. Unlike some other forms of extra-parliamentary civic activism that challenge the existing political system per se, resident activists typically are not mobilised by constructing enemy images of the state. Rather, they assume responsibility over their own living conditions beyond the existing political system and its powers. In this sense, local resident activism may be considered as a parallel to the traditional, election-bound sphere of representation. The two spheres are not, judged by our empirical data, in a competitive relationship but pursue the good of the community each within their own boundaries and resources. As Laura Montanaro (2012: 1094) argues, such action satisfies the basic normative intuition lying at the heart of most contemporary democratic theories, that 'those potentially affected by a collective decision should have opportunities and capacities to influence that decision.' Moreover, she (2012: 1096) justifies self-appointed representatives by claiming that 'such constituents embody the Tocquevillian norm of participation in local associations as a key mechanism for a healthy democracy.'

When we think about the legitimacy of local democracy in Finland (or elsewhere, for that matter) from the point of view of traditional party-based democracy, the development whereby residents are trying to expand their autonomy vis-à-vis the local government may appear to be a problem. However, taking into consideration the problems of current democracy and its need for change, resident-oriented local democracy can be regarded as an appealing model that can build more on people's own activeness and well-being than simply running a municipal bureaucracy as effectively as possible. In emphasising openness, horizontality, and cooperation-based DIY practices, resident activism comes closer to the basic ideal of democracy as the people's selfgovernment, and indeed, in this sense, it can be interpreted as being a type of protodemocratic politics. Resident activism allows people more immediate and concrete means of affecting their own locality than does the traditional political system with its mechanisms of political representation alone. 


\section{Notes}

1 Resident-related concepts are not suggested here as exclusionary categories. Rather, any single citizen can be classified using a number of concepts (e.g., as a voter, participant, party, or NGOactivist, resident activist, etc) depending on the research problem/questions and the theoretical framework at hand.

2 For example, in the southern city of Järvenpää, local residents initiated guerilla gardening projects in order to improve the city's unattractive corners, and in the city of Vantaa, which is part of the metropolitan area surrounding Helsinki, the local 'Myyrmäki' movement took it upon itself to renovate an entire train station, setting up the largest ever mural art project seen in the north of Europe. In a number of Finnish municipalities, residents have started to fight literally against windmills (opposing their locations being too close to existing settlements), and in Lapland, the citizens' mining forum has promoted more critical public discussion on the growing presence of global mining corporations in the region. Residents have also stood up to defend the preservation of public services like primary schools and health centres and occasionally created their own service concepts to make up for losses of prior public services. Moreover, during the fall of 2015 a new burst of local resident activism sprang up in reaction to the refugee crisis that shocked all of Europe.

3 The media analysis revealed seven main themes around which the local resident movements in Finland work and act: 1.Nearby living environment, 2. Nearby natural environment, 3. Public services and residents' wellbeing, 4. Place-based identity and residents' sense of community, 5. Economic viability of the locality, 6. Local democracy, 7. Appeal and future of the locality. (Here locality does not equal the whole municipality. Often residents referred specifically to their own area and neighborhood instead of a larger geographical and political unit.) It should be noted that, in our interviews, the thematic variety of the resident movements' activities bore no influence on the way the activists defined their relationship to local democracy and understood the representativeness of their own activity.

4 In the interview, some background information was first inquired about the activist's place of residence, subjective meanings given to it, and earlier experiences of civic activism. Thematic questions were designed to find out about the activists' a) objectives of action; b) experiences of political influencing activity and means of influence; c) views of the representativeness of their action and the performance of current municipal democracy; d) opinions about the ongoing municipal and 'Sote' (social and health care) reform; and e) experiences of their perceived effects of resident activism on the feelings of security in the locality.

5 The interviewees' conceptions of the representativeness of their actions was enquired through the following questions: a) Who and what issues do you think you represent in your activities? b) What does representation mean to you? c) Is representing important for citizens' and residents' influencing 
activities? d) Do you prefer acting alone or acting together with others?

6 Category 1: Meanings given to action by the activists. Category 2: Activists' relationship to other residents in the locality. Category 3: Activists' relationship to local administration and political decision-making. 


\section{References}

ADAMS, JASON M. 2014. Occupy Time: Technoculture, Immediacy, and Resistance after Occupy Wall Street. New York, NY: Palgrave McMillan.

ANKERSMIT, FRANKLIN. 2002a. Political Representation. Stanford, CA: Stanford University Press.

ANKERSMIT, FRANKLIN. 2002b. Representational democracy. An aesthetic approach to conflict and compromise. Common Knowledge 8 (1): 24-46.

ARTER, DAVID. 1999. Scandinavian political system. Manchester \& New York: Manchester University Press.

BENGTSSON, ÅSA and CHRISTENSEN, HENRIK. 2016. Ideals and Actions: Do Citizens' Patterns of Political Participation Correspond to their Conceptions of Democracy? Government and Opposition, 51 (2): 234-260.

BOGGS, CARL. 1977. Marxism, prefigurative Communism, and the problem of workers' control. Radical America 11 (6): 99-122.

DELlA PORTA, DONATELLA (ed). 2009. Another Europe. Conceptions and Practices of Democracy in the European Social Forums. London: Routledge.

DELLA PORTA, DONATELLA. 2013. Can Democracy be Saved? Participation, Deliberation and Social Movements. Cambridge, UK: Polity Press.

DIANI, MARIO. 2015. The Cement of Civil Society: Studying Networks in Localities. Cambridge: Cambridge University Press.

DRURY, JOHN, CHRISTOPHER COCKING, JOSEPH BEALE, CHARLOTTE HANSON and FAYE RAPLEY. 2005. The phenomenology of empowerment in collective action. British Journal of Social Psychology 44 (3): 309-328.

FABIAN, LOUISE and K. SAMSON. 2015. Claiming participation - a comparative analysis of DIY urbanism in Denmark. Journal of Urbanism. International Research on Placemaking and Urban Sustainability 9 (2): 1-19

FOMINAYA, CRISTINA F. 2010. Collective identity in social movements: central concepts and debates. Sociology Compass 4: 393-404. 
GAUS, GERALD F. 2008. The (severe) limits of deliberative democracy as the basis for political choice. Theoria: A Journal of Social \& Political Theory 55 (117): 26-53.

GERBAUDO, PAOLO. 2012. Tweets and the Streets. Social Media and Contemporary Activism. London: Pluto Press.

GILSTER, MEGAN E. 2013. Putting activism in its place: The neighborhood context of participation in participation in neighborhood-focused activism. Journal of Urban Affairs 36 (1): 33-50.

HELLER, AGNES and FERENC FEHER. 1989. The Postmodern Political Condition. New York, NY: Columbia University Press.

JURIS, JEFFREY S. 2012. Reflections on \#occupy everywhere: Social media, public space, and emerging logic of aggregation. American Ethnologist 39 (2): 259-279.

KEANE, JOHN. 2009. The Life and Death of Democracy. New York, NY: W. W. Norton \& Company Inc.

KRIPPENDORFF, KLAUS. 2012. Content Analysis: An Introduction to Its Methodology. Thousand Oaks, CA: Sage.

MANSBRIDGE, JANE. 2011. Clarifying the concept of representation. American Political Science Review 105 (3): 621-630.

McADAM, DOUG, ROBERT SAMPSON, SIMON WEFFER and HEATHER MACINDOE. 2005. "There will be fighting in the streets". The distorting lens of social movement theory. Mobilization: An International Quarterly 10 (1): 1-18.

MONTANARO, LAURA. 2012. The democratic legitimacy of self-appointed representatives. The Journal of Politics 74 (4): 1094-1107.

NÄSSTRÖM, SOFIA. 2011. Where is the Representative Turn Going? European Journal of Political Theory 10 (4): 501-10.

PAPACHARISSI, ZIZI. 2015. Affective Publics. Sentiment, Technology, and Politics. Oxford, UK: Oxford University Press.

PITKIN, HANNA F. 1972 [1967]. The Concept of Representation. Berkeley, CA: University of California Press. 
RANCIÈRE, JACQUES. 2006. The Politics of Aesthetics: The Distribution of the Sensible. Translated with an introduction by Gabriel Rockhill [with an afterword by Slavoj Žižek]. London: Continuum.

REHFELD, ANDREW. 2011. The concepts of representation. American Political Science Review 105 (3): 631-641.

SAMPSON, ROBERT, DOUG McADAM, HEATHER MACINDOE and SIMON WEFFERELIZONDO. 2005. Civil society reconsidered: The durable nature and community structure of collective civic action. American Journal of Sociology 111 (3): 673-714.

SAWARD, MICHAEL. 2010. The Representative Claim. Oxford: Oxford University Press.

SEVERS, ELINE. 2010. Representation as claims-making. Quid responsiveness? Representation 46 (4): 411-423.

STREET, JOHN. 2004. Celebrity politicians: Popular culture and political representation. British Journal of Politics and International Relations 6 (4): 435-52.

TORMEY, SIMON. 2015. The End of Representative Politics. Cambridge: Polity Press.

URBINATI, NADIA. 2006. Representative Democracy: Principles and Genealogy. Chicago, IL: Chicago University Press.

URBINATI, NADIA and MARK WARREN. 2008. The concept of representation in contemporary democratic theory. Annual Review of Political Science 11 (June 2008): 387-412.

YATES, LUKE. 2015. Rethinking prefiguration: Alternatives, micropolitics, and goals in social movements. Social Movement Studies 14 (1): 1-21.

ZAHAVI, DAN. 2009. Is the self a social construct? Inquiry. An Interdisciplinary Journal of Philosophy 52 (6): 551-572.

WILLS, JANE. 2016a. Locating Localism: Statecraft, Citizenship and Democracy. Bristol: Policy Press.

WILLS, JANE. 2016b. Emerging geographies of English localism: The case of neighbourhood planning. Political Geography 53 (July 2016): 43-53. 